\title{
PERBEDAAN FATWA-FATWA SAHABAT SEBAGAI SUMBER HUKUM ISLAM
}

\author{
Paryadi dan Sadari \\ STIS Hidayatullah Balikpapan \\ INISA Tambun-Bekasi \\ semangatmas@gmail.com \\ arifahmikhan@gmail.com
}

\begin{abstract}
Abstrak
Perbedaan-perbedaan fatwa yang terjadi dikalangan para sahabat disebabkan dua hal pertama, karena terjadinya kontak dan saling mempengaruhi antara Islam dan budaya-budaya lain yang bertetangga dengannya. Wilayah dan budaya yang dihadapi para sahabat sangat bervariasi tipologi dan permasalahannya. Kedua, kemampuan para sahabat tidak pada satu tingkat yang sama dalam ilmu mereka dalam memahami sunnah terkait hal ihwal sabda Rasulullah, keadaan mereka bertingkat-tingkat ada diantara mereka yang menghabiskan umurnya untuk selalu bersama Rasulullah siang, malam, saat berada dirumah atau bepergian, saat puasa maupun tidak, saat senang atau susah, saat jihad atau ibadah dan melayani sebagai besar kegiatan beliau seperti Anas bin Malik. Ada juga yang sering mengembara dipedalaman atau berdagangan diberbagai daerah. Ada pula yang hanya melihat sekali Nabi Saw, pada kesempatan haji wada'. Juga sda yang menetap ataupun yang nomaden sehingga sangat wajar dan logis kalau para ulama sepakat bahwa kemampuan sahabat bertingkat-tingkat. Dalam meyikapi perbedaan-perbedaan fatwa maka harus ada kritik internal terhadap sejumlah tradisi yang dikenal oleh umat Islam untuk dapat memisahkan apakah suatu ayat atau tradisi tertentu cocok diterapan pada situasi tertentu. Karena sejak awal-awal Islam telah terjadi benturan yang tak dapat dihindari antara hukum yang tersurat dengan semangat yang terkandung didalamnya. Jadi perbedaan tersebut karena penafsiran dan penerapan yang digunakan dengan pertimbangan pribadi sahabat terhadap persoalan-persoalan yang belum diperoleh petunjuknya dalam al-Qur'an dan Hadits.
\end{abstract}

Kata Kunci: perbedaan fatwa; sahabat; sumber hukum Islam 


\section{A. Pendahuluan}

Setelah wafatnya Rasulullah, para sahabat tersebar di berbagai polosok dunia Islam. Umumnya mereka menduduki posisi kepemimpinan keagamaan dan intelektual. Mereka menjadi tempat bertanya orang-orang di daerahnya untuk dimintai keputusan berkaitan dengan berbagai persoalan. Mereka memberikan keputusan kadang-kadang berdasarkan apa yang pernah mereka pelajari dan ingat dari perintah-perintah Rasulullah, dan dilain waktu menurut apa yang mereka pahami dari al-Qur'an dan as-Sunnah. Sering mereka membentuk pendapat sendiri dengan nilai syari'ah ('illat) yang menuntun Rasulullah untuk mengambil keputusan. ${ }^{1}$

Ibnu Qayyim menjelaskan bahwa pendapat para sahabat lebih mendekati pada al-Qur'an dan as-Sunnah dibandingkan pendapat para ulama yang hidup sesudah mereka. Beliau mengatakan: "Bila seorang sahabat mengemukakan suatu pendapat, atau menetapkan suatu hukum, atau memberikan suatu fatwa, tentu ia telah mempunyai pengetahuan, baik yang hanya diketahui oleh para sahabat, maupun pengetahuan yang tidak kita miliki. Adapun pengetahuan khusus yang diketahui sahabat, mungkin didengar langsung dari Rasulullah atau didengar dari Rasulullah melaluli sahabat yang lain". ${ }^{2}$ Tentu pengetahuan yang dimiliki oleh masing-masing para sahabat banyak sekali dan berbeda-beda.

Bersamaan dengan itu maka konskuensinya terjadi perbedaan pendapat dan praktek yang kontradiksi diantara para sahabat dalam satu kasus yang sama tidak bisa dihindari. Salah satu contoh, sekali waktu Ibnu Mas'ud dikabarkan pernah ditanya apakah seorang wanita sepatutnya diberikan mahar jika suaminya meninggal sebelum menetapkan besar maharnya dan sebelum keduanya tidur bersama. Ibnu Mas'ud pada pertama kalinya menjawab bahwa ia belum pernah mendengar sesuatu dari Rasulullah mengenai maslah tersebut.

\footnotetext{
${ }^{1}$ Ahmad Hasan, Pintu Ijtihad Sebelum Tersebut (Bandung, Pustaka 1970), 14

2 Muhammad Abu Zahrah, Ushul Fiqh (Jakarta: Pustaka Firdaus, 1994), 330.
} 
Tetapi ketika ia diminta untuk memberikan saran. Ia berpendapat bahwa perempuan tersebut harus diberi mahar sebanyak rata-rata mahar sebanyak rata-rata mahar seorang perempuan pada tingkat sosial yang sama. Lebih jauh ia menyarankan bahwa perempuan itu berhak menerima hak waris penuh dari warisan suaminya dan baginya ada iddah. Maqil bin Sinan (w $64 \mathrm{H}$ ) dikabarkan ia hadir dalam kejadian itu dan mengatakan bahwa Rasulllulah dahulu telah memberikan keputusan yang sama.

Namun Ibnu 'Umar (w, 73 H) dan Zayd bin Tsabit (w, 45 H) dikabarkan telah memeberikan keputusan berbeda dalam kasus yang sama. Menurut mereka berdua, janda yang demikian tak akan mendapatkan mahar sedikitpun, tetapi mereka hanya akan memperoleh bagiannya dalam warisan. Orang-orang Irak mengikuti pendapat Ibnu Mas'ud dan menolak pendapat Ibnu'Umar dan Zayd bin Tsabit. ${ }^{3}$

Apabila dinyatakan bahwa kedua pendapat tersebut dilandaskan pada tradisi, maka tak satupun dari kedua pendapat yang bertentangan itu yang akan bisa dikatakan berasal dari tradisi Rasulullah. Karena, seandaikan ada keputusan jelas dari Rasulullah mengenai suatu masalah sosial yang demikian pentingnya seperti pernikahan, bagaimana mungkin perbedaan pendapat yang bertolak belakang seperti itu dapat terjadi? Sangat sulit dipercaya bahwa keputusan Rasulullah dalam masalah demikian penting tetap tinggal sedemikian pribadinya dan tidak tersiarkan, sehingga hanya diketahui oleh satu atau dua orang sahabat saja.

Kemudian masih banyak lagi perbedaan fatwa-fatwa para sahabat dalam menyikapi kasus yang sama terutama sahabat Umar bin Khattab. Padahal dam keseluruhan, para imam dari imam madzhab mengikuti fatwa-fatwa sahabat, dan tidak menghindarinya.

Dalam pembahasan artikel ini, penulis sangat tertarik untuk mendapatkan jawaban akademis tentang, faktor-faktor yang menyebabkan perbedaan fatwa-fatwa sahabat dan menyikap atau memposisikan perbedaan fatwa-fatwa para sahabat tersebut dalam sumber hukum Islam.

\footnotetext{
${ }^{3}$ Ahmad Hasan, Pintu Ijtihad Sebelum Tertutup (Bandung: Pustaka 1970), 14.
} 


\section{B. Definisi Sahabat}

Sahabat secara etimologi merupakan kata bentuk dari kata ash-shuhbah (persahabatan), yang tidak mengandung pengertian persahabatan dalam ukuran tertentu. Tetapi berlaku untuk orang yang menyertai orang lain, sedikit ataupun banyak sama seperti kata mutakallim, mukhattab dan dharib, berasal dari bentuk mukalamah (pembicaraan), mukhathaba (ceramah), dharb (pukulan), dan berlalu untuk siapa saja yang melakukan hal-hal itu, sedikit atau banyak. ${ }^{4}$

Sahabat adalah orang-orang yang bertemu Rasulullah, langsung menerima risalahnya, dan langsung mendengar penjelasan syari'at dari beliau sendiri. ${ }^{5}$ Imam Bukhari di dalam kitab shahihnya mengatakan, "di antara kaum muslimin yang pernah menyertai Rasulullah atau pernah melihatnya". Ibnu Hazm ra berkata, "adapun yang dimaksud sahabat adalah setiap orang yang pernah bermujalasah dengan Rasulullah, meskipun hanya sesaat, mendengar dari beliau walaupun hanya satu kata, menyaksikan beliau menangani suatu masalah dan tidak termasuk orang munafiq yang kemunafikannya berlanjut popular dan meninggal dalam keadaan begitu."6

4 Muhammad 'Ajaj Al-Khattib, Ushul al-Hadis (Jakarta: Gaya Media Pratama, 1997), 377.

${ }^{5}$ Muhamad Abu Zahra, Ushul Fiqh (Jakarta: Pustaka Firdaus, 1994), 328.

6 Muhammad 'Ajaj Al-Khattib, Ushul al-Hadis (Jakarta: Gaya Media Pratama, 1997), 377. 


\section{Kedudukan sahabat}

Dengan demikian Jumhur Fuqaha' telah menetapkan bahwa pendapat para sahabat dapat dijadikan hujjah sesudah dalil nash. Mereka mengemukakan argumentasi, baik dengan dalil aqli dan naqli tentang kedudukan sahabat Rasulullah dalam Islam. Dalil naqli diantaranya: Firman Allah dalam surat at-Taubah ayat 100:

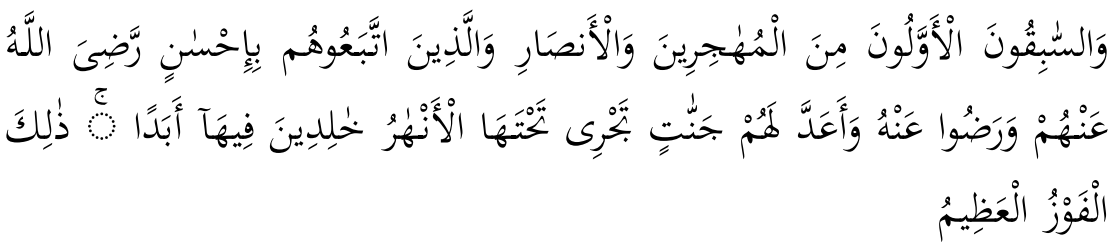

Artinya "orang-orang terdahulu lagi yang pertama-tama (masuk Islam) diantara orang-orang muhajirin dan anshor dan orang-orang yang mengikuti mereka dengan baik, Allah ridha kepada mereka dan mereka pun ridha kepada Allah."

Kemudian sabda Rasulullah: "perpegang teguhlah pada Sunnahku dan Sunnah Khulafa'urrayidin yang mendapat petunjuk. Pegang teguhlah dan gigitlah ia dengan gigi geraham. Hindarilah perkata-perkata (keagamaan) yang model-model. Karena setiap kemodelan adalah bid'ah dan setiap bid'ah adalah kesesatan.

Sedangkan argumentasi aqli (rasional), para sahabat adalah orang-orang yang lebih dekat dengan Rasulullah dibandingkan orang lain. Dengan demikian mereka lebih mengetahui tujuan-tujuan syara', lantaran mereka menyaksikan langsung tempat dan waktu turunya al-Qur'an, mempunyai ke ikhlasan dan penalaran yang tinggi, ketaat yang mutlak terhadap petunjuk-petunjuk Nabi.

Disamping itu, kadang-kadang ulama memahami asSunnah sebagai amalan para sahabat. Permasalahan itu baik, berkenaan dengan yang ada dalam al-Qur'an maupun yang mereka ambil dari Rasulullah, karena ia adalah merupakan wujud mengikuti sunnah yang ada pada mereka atau ijtihad yang merupakan konsensus diantara mereka. ${ }^{8}$

\footnotetext{
${ }^{7}$ Abu Daud dalam sunnahnya, Juz. IV, 281.

8 Muhammad 'Ajaj Al-Khattib, Ushul al-Hadis (Jakarta: Gaya Media Pratama, 1997), 5.
} 


\section{Sumber Hukum Islam}

Menurut Islam, sumber wewenang yang tertinggi adalah Allah semata. ${ }^{9}$ Dalam cita hukum Islam, semua kecuali Allah, termasuk Rasulullah, sahabat, fuqaha dan penguasa, adalah tunduk pada hukum Allah, yang berasal dari wahyu samawi. Hukum Islam terlepas dari keseragaman-sumbernya-berasal dari Allah dan berusaha untuk menemukan dan merumuskan kehendaknya. Namun kehendak Allah bukanlah suatu sistem yang statis dan telah ditentukan untuk berlaku selamanya tanpa mengalami perubahan.

Perwujudan dari kehendak Allah adalah al-Qur'an yang diturunkan kepada Rasulullah Saw. Wahyu turun, lalu Rasulullah menyampaikan hukum-hukumnya dalam kehidupan sehari-hari. Sehingga Rasulullah menjadi rujukan utama dalam mengatasi permasalahan umat, baik dalam bidang hukum, fatwa, peraturan keuangan maupun perpolitikan dan kemiliteran. Beliau menangani permasalahan tersebut atas kesaksian para sahabat. ${ }^{10}$

Aplikasi dari hukum Islam tidak begitu pelik dizaman Rasulullah masih hidup karena keputusan beliau merupakan kata akhir. Satu-satunya yang ideal pada waktu itu hanyalah Rasulullah. Para sahabat belajar wudhu, menjalankan shalat, puasa, haji dan lain-lainya dengan cara mengamati tindakan normatif dari Rasulullah, dibawah petunjuk beliau langsung. Tetapi mereka tidak membagi-bagi bagian mana dari tindakan Rasulullah yang mengandung arkan (rukun-rukun) dan yang mengandung $a d a b$ (sunah). ${ }^{11}$

Tetapi setelah Rasulullah wafat persoalan semakin lama semakin pelik. Sebab para sagabat memiliki dua landasan untuk memutuskan kasus-kasus yang baru yaitu al-Qur'an dan preseden-preseden yang ditinggalkan Rasulullah. Sementara kebanyakan persoalan yang dihadapi kaum muslimin yang hidup dimasa Rasulullah tentu berbeda dengan yang dihadapi generasi berikutnya.

\footnotetext{
${ }^{9}$ Ahmad hasan, Pintu Ijtihad Sebelum Tertutup (Bandung: Putaka 1970), 28.

${ }^{10}$ Muhammad 'Ajaj Al-Khattib, Ushul al-Hadis (Jakarta: Gaya Media Pratama, 1997), 72.

${ }^{11}$ Ahmad hasan, Pintu Ijtihad Sebelum Tertutup (Bandung: Putaka 1970), 106.
} 
Posisi sahabat adalah sebagai kunci untuk membuka pintu pemahaman umat Islam terhadap sumber hukum Islam yaitu alQur'an dan Hadits. Umat Islam juga sangat membutuhkan ilmu, pengetahuan, dan periwayatan sahabat dalam menangani masalah-masalah baru yang muncul dihadapan mereka. Mereka (sahabat) sangat antusias dalam memegang teguh Sunnah, kebaikan penelitian kepada Rasulullah, kedisiplinan mereka terapkam dalam hukum Islam.

Sehingga sangat wajar Imam Abu Hanifah berkata: "jika kami tidak menjumpai dasar-dasar hukum dari al-Qur'an dan Hadits, maka kami mempergunakan fatwa-fatwa sahabat". Pendapat para sahabat tersebut, ada yang diambil, ada pula yang kami tinggalkan. Akan tetapi tidak akan beralih dari pendapat mereka kepada pendapat selain mereka.

Diriwayatkan juga Ar-Rabi', bahwa Imam Syafi'i didalam kitab al-Umm berkata: "jika kami tidak menjumpai dasar-dasar hukum dari al-Qur'an dan Hadits, maka kami kembali kepada pendapat para sahabat atau salah seorang dari mereka. Kemudia jaka kami harus bertaqlid, maka kami tidak menjumpai dilalah (dalil-dalil) dalam ikhtilaf yang menunjukan pada ikhtilaf yang lebih dekat kepada al-Qur'an dan as-Sunnah, niscaya kami mengikuti pendapat yang mempunyai dilalah."12

Ada beberapa sumber yang bisa menjadi rujukan normatif menyikapi ijtihad, seorang hakim tentunya diperbolehkan untuk melakukan ijtihad, karena Rasulullah bersabda:

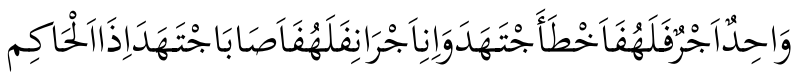

Artinya: "Hakim apabila berijtihad kemudian dapat mencapai kebenaran maka ia mendapat dua pahala. Apabila ia berijtihad kemudian tidak mencapai kebenaran, maka ia mendapat satu pahala", ${ }^{13}$

${ }^{12}$ Ahmad hasan, Pintu Ijtihad Sebelum Tertutup (Bandung: Putaka 1970), 106. Muhammad Abu Zahrah, Ushul Fiqh (Pustaka Firdaus: Jakarta-1994), 332.

${ }^{13}$ HR. Al-Bukhari 13/268 dan Muslim No. 1716. 
Perbedaan pendapat akan hasil berijtihad, bisa dikarenakan kemampuan penalaran seseorang terbatas, maka hasil dari ijtihad bersifat relatif sehingga memungkinkan diantara mujtahid berbeda pendapat dengan mujtahid lainnya. ${ }^{14}$ Rasulullah juga pernah bersabda, "Janganlah kalian merasa diri kalian suci, Allah lebih tahu akan orang-orang yang berbuat baik diantara kalian" (HR. Muslim).

Allah Swt melarang kita untuk menganggap diri kita paling baik dan benar karena itu adalah salah satu sikap dari kaum munafiq, Allah Swt berfirman:

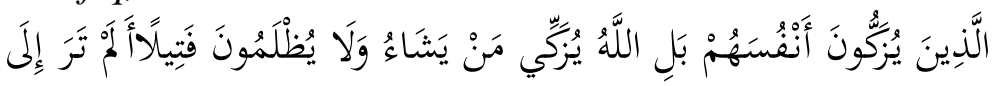

Artinya: "Apakah kami tidak memperhatikan orang yang menganggap dirinya bersih. Sebenarnya Allah mensucikan siapa yang dikehendaki-Nya dan mereka tidak dianiaya sedikit pun." (QS. an-Nisa: 49).

${ }^{14}$ Nuril Huda, Memahami Islam Lewat Perguruan Tinggi (Jakarta: Amsah, 2017), 76. 


\section{E. Macam-macam Fatwa Sahabat}

Abu Bahkar ash-Shiddiq selalu mendampingi Rasulullah sejak sebelum beliau diutus Allah hingga wafatnya, dan hampihampir beliau tidak pernah lepas dari pemantauan Abu Bakar sehingga bisa digolongkan orang yang paling mengetahui ucapan, perbuatan, petunjuk dan segala aktifitas Rasulullah. Akan tetapi hadis-hadis yang meriwayatkan darinya tidak lebih dari 100 hadis. Demikian juga sahabat yang lain jumlah sangat sedikit dibandingkan dengan apa yang mereka dengar dan lihat dari Rasulullah.

1) Para sahabat sangat berhati-hati dalam meriwayatkan hadis Rasulullah karena khawatir terjerumus dalam kesalahan dan karena takut ada kesalahan masuk dalam sunnah. Padahal sunnah merupakan sumber hukum pertama setelah al-Qur'an. Bahkan ada diantara mereka yang membatasi diri dari periwayatan hadis karena alasan menghormati bukan karena enggan terhadapnya. ${ }^{15}$ Karena itu, mereka sedikit sekali meriwayatkan hadits dan hanya menceritakan apa yang mereka dengar dari Rasulullah berulang-ulang kali. Dengan demikian fatwa-fatwa sahabat tidak keluar dari enam kemungkinan sebagaimana berikut ini: ${ }^{16}$

2) Fatwa tersebut mereka dengar langsung dari Rasulullah

3) Fatwa tersebut dengar dari sahabat yang mendengarkan fatwa dari Rasulullah

4) Fatwa tersebut mereka pahami dari ayat-ayat suci al-Qur'an yang belum jelas

5) Fatwa tersebut telah mereka sepakati, akan tetapi hanya disampaikan oleh seorang mufti

6) Fatwa tersebut merupakan pendapat sahabat secara pribadi, lantaran mereka menguasai bahasa Arab secara sempurna sehingga mereka mengetahui dilalah lafadz terhadap sesuatu yang tidak kita ketahui

7) Mungkin fatwa tersebut dari pemahaman sahabat sendiri yang tidak berasal dari Hadits Rasulullah, dan ternyata pemahaman tersebut salah. Namun kemungkinan ini tidak dapat dijadikan hujjah, akan tetapi yang lima kemungkinan diatas yang sering terjadi dan lebih mendekati kebenaran

15 Muhammad 'Ajaj Al-Khattib, Ushul al-Hadis (Jakarta: Gaya Media Pratama, 1997), 5.

${ }^{16}$ Muhammad Abu Zahrah, Ushul Fiqh (Pustaka Firdaus: Jakarta-1994), 331. 


\section{F. Pendapat Kontra}

Ternyata ada diantara para ulama yang tidak menganggap pendapat sahabat sebagai hujjah, bahkan menanggapnya tidak mungkin (mustahil) sebagaimana yang dikatan oleh ashSyaukani: "sebenarnya, pendapat sahabat tidak dapat dijadikan hujjah. Karena Allah hanya mengutus seorang Nabi kepada umat ini, yaitu nabi Muhammad Saw, Rasul kita sahabat maupun generasi sesudahnya semua diperintahkan untuk mengikuti kitab Suci al-Qur'an dan Hadis." 17

Jika dilihat dari perbedaan dikalangan sahabat bermula setelah Rasulullah wafat. Perbedaan itu dikarenakan beberapa faktor, antara lain:

Pertama, diantara sahabat ada yang telah mendengar sebuah hukum dari suatu kasus atau fatwa (dalam bahasa Arab artinya adalah nasihat, petuah, jawaban atau pendapat) dari Rasulullah, tapi sahabat yang lain belum mendengar jawaban Rasulullah, sebab itu yang menjadikan sahabat berijtihad.

Kedua, para sabahat melihat Rasulullah melakukan suatu amalan, lalu ada sahabat yang menyimpulkan bahwa hal itu suatu ibadah dan ada yang menyebutnya sebagai sesuatu hal yang mubah.

Ketiga, perselisihan atau berbedaan dalam menentukan 'illah sebuah hukum. Contohnya, masalah berdiri untuk jenazah. Dalam hal ini ada yang berpendapat bahwa berdiri ketika ada jenazah adalah sebagai ajang untung mengingat kematian. Namun ada juga yang berpendapat bahwa Rasulullah berdiri ketika lewat di depannya mayat karena beliau tidak ingin lebih rendah dari jenazah tersebut. ${ }^{18}$

${ }^{17}$ Muhammad Abu Zahrah, Ushul Fiqh (Pustaka Firdaus: Jakarta-1994), 335.

${ }^{18}$ Lihat Abu Malik Kamal bin as-Sayyid Salim, Shahih Fiqih Sunnah: Ilmu Fiqih pada Zaman Sahabat (Jakarta : Pustaka at-Tazkia, 2012), 22-24. 


\section{G. Penutup}

Islam pada masa-masa awal tertancap kokoh dihati para sahabat yang memeluk dan mengikuti al-Qur'an dan berpegang teguh kepada prinsip-prinsip yang diajarkan oleh Rasulullah. Kita semua sepakat dengan keadilan seluruh sahabat. Keadilan mereka tidak perlu diteliti ulang selama tidak ada kritik kepada mereka. Karena dikhawatirkan menyimpang dari hadis yang telah menjelaskan keutamaan dan keadilan mereka.

Sebagaimana sabda rasulullah dari Abu Musa: "Bintangbintang adalah amanah bagi langit. Bila bintang-bintang itu sirna, maka langit akan menemui apa yang dijanjikan kepadanya. Aku adalah amanah bagi sahabat-sahabat. Bila aku tiada, maka sahabat-sahabatku akan menemui apa yang dijanjikan kepada mereka. Sahabat-sahabatku adalah amanah umatku. Apabila sahabat-sahabatku telah tiada, maka umatku akan menemui apa yang dijanjikan kepada mereka."

Adapun pendapat Ash-Shaukani yang menolak pendapat para sahabat maka sebenarnya para imam madzhab mengikuti pendapat sahabat bukan berarti mereka menciptakan risalah baru selain risalah Rasulullah, dan menganggap hujjah itu pada selain al-Qur'an dan Hadis. Karena walaupun mereka mengambil pendapat sahabat, mereka tetap berpegang pada satu kitab yaitu al-Qur'an dan satu nabi yaitu Muhammad Saw. 


\section{Daftar Pustaka}

Abdirrazaq, Abu Hafsh Usamah bin Kamal bin 'Abdir, Panduan Lengkap Nikah dari "A" sampai "z": Nikah tidak Sah kecuali dengan Keberadaan Wali, Jakarta: Pustaka ibnu Katsir, 2016.

Al-Bakar, 'Abdul Qodir Mahmud, Kitab Ash-Sholatu 'Alaal Madzaahabil Arba'ati: Sebab Ikhtilaf Para Ulama, Kairo: Linasyir, 1893.

Al-Bakar, Abdul Qodir Mahmud. Kitabussholah 'Alaal Madzaahabil Arba'ah, Kairo: an-Nasyir, 1893.

Al-Khattib, Muhammad 'Ajaj, Ushul Al-Hadis, Jakarta: Gaya Media Pratama, 1997.

Daud, Abu dalam sunnahnya, Juz IV, 281.

Hasan, Ahmad, Pintu Ijtihad Sebelum Tertutup, Bandung: Pustaka 1970.

Huda, Nuril, Memahami Islam Lewat Perguruan Tinggi, Jakarta: Amsah, 2017.

Mughniyah, Muhammad Jawad, Fiqih Lima Madzhab: Imam Syafi'i Jakarta: Lentera Basritama, 1996.

Salim, Abu Malik Kamal bin as-Sayyid, Shahih Fiqih Sunnah: Ilmu Fiqih pada Zaman Sahabat, Jakarta: Pustaka atTazkia, 2012.

Zahra, Muhamad Abu, Ushul Fiqh, Jakarta: Pustaka Firdaus, 1994. 